\title{
Interesting rotifers (Rotifera: Eurotatoria) from floodplain lakes of lower Brahmaputra river basin of Assam, northeast India
}

\author{
B.K. SHARMA ${ }^{1} \&$ S.I. KHAN \\ Bhushan Kumar Sharma \& Shaikhul Islam Khan, Freshwater Biology Laboratory, Department of \\ Zoology, North-Eastern Hill University, Shillong 793 022, Meghalaya, India. E-mail: \\ profbksharma@gmail.com ( ${ }^{1}$ corresponding author)
}

\begin{abstract}
The plankton and semi-plankton samples collected from four floodplain lakes (beels) of Barpeta district of lower Brahmaputra river basin, Assam state, northeastern India (NEI) revealed eighteen rotifer species of biodiversity and biogeographic interest belonging to five families and six genera. One species is new to the Indian Rotifera and one species is new to Assam. Our collections are characterized by two Australasian elements, five Oriental endemics, seven paleotropical species, and one cosmo (sub) tropical species. Nine species, restricted to date to NEI, are examples of regional distribution importance in India while six species depicted disjunct distribution in the country. Interestingly, seven species are categorized as Eastern hemisphere elements. All the taxa are illustrated to warrant validation as an increasing magnitude of 'unverifiable records' is a serious impediment for the progress of rotifer biodiversity in India.
\end{abstract}

Keywords. Biodiversity, distribution, interesting taxa, lower Assam, tropical floodplains.

\section{INTRODUCTION}

$\mathrm{T}$ ropical and subtropical floodplain lakes are hypothesized to be Rotifera rich habitats (Segers et al. 1993). The rotifer assemblages of these ecotones are poorly documented in India in general except for the floodplain lakes (beels) of the Brahmaputra river basin of Assam state which are known for their rich and interesting rotifer diversity (Sharma \& Sharma 2005, 2008, 2013, 2014a, 2014b, 2014c, 2015a) in the Indian subregion. The present limnological reconnaissance is undertaken to further explore the biodiversity importance of 'managed beels' (for fisheries) of Barpeta district of lower Assam. During the course of the study, we observed eighteen Rotifera species of biodiversity and biogeographic value. The recorded species are listed and comments are made on their status, occurrence, and distribution. All the taxa are illustrated to warrant validation as the Indian literature is flooded with 'ad-hoc unverifiable' reports lacking validations (BKS, unpublished).

\section{MATERIALS AND METHODS}

This study is a part of limnological reconnaissance undertaken in four floodplain lakes (beels) of Barpeta district of Assam (Table 1) during August 2011 - July 2013. These beels are 'managed' locally to harvest their fishery potential. Plankton and semi-plankton samples were collected from various beels by towing a nylobolt plankton net $(\# 50 \mu \mathrm{m})$ and were preserved in $5 \%$ formalin. Individual collections were screened with a Wild stereoscopic binocular microscope; the rotifer taxa were isolated and mounted in Polyvinyl alcohol-lactophenol, and were observed with Leica (DM 1000) stereoscopic phase contrast microscope fitted with an image analyzer. The different rotifers were identified following the works of Koste (1978), Segers (1995), Sharma (1983, 1987, 1998), Sharma \& Sharma (1997, 1999, 2000, 2008, 2013, 2015a, 2015b, 2015c). The reference materials are in the holdings of Freshwater Biology laboratory, Department of Zoology, NorthEastern Hill University, Shillong. 
Table 1. List of the sampled beels.

\begin{tabular}{|c|c|c|c|c|}
\hline Sl. No. & Beel & Latitude & Longitude & Elevation $(\mathrm{m})$ \\
\hline 1 & Fingua & 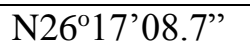 & E9102'00.2” & 37.9 \\
\hline 2 & Baria & N 2621'35.9”' & E 9102'43.1” & 43.7 \\
\hline 3 & Sorbhog & N2630'22.2”' & E90'53'20.6”' & 48.3 \\
\hline 4 & Balaisuti & N26 $21^{\prime} 19.7^{\prime \prime}$ & E90'52'12.8' & 54.6 \\
\hline
\end{tabular}

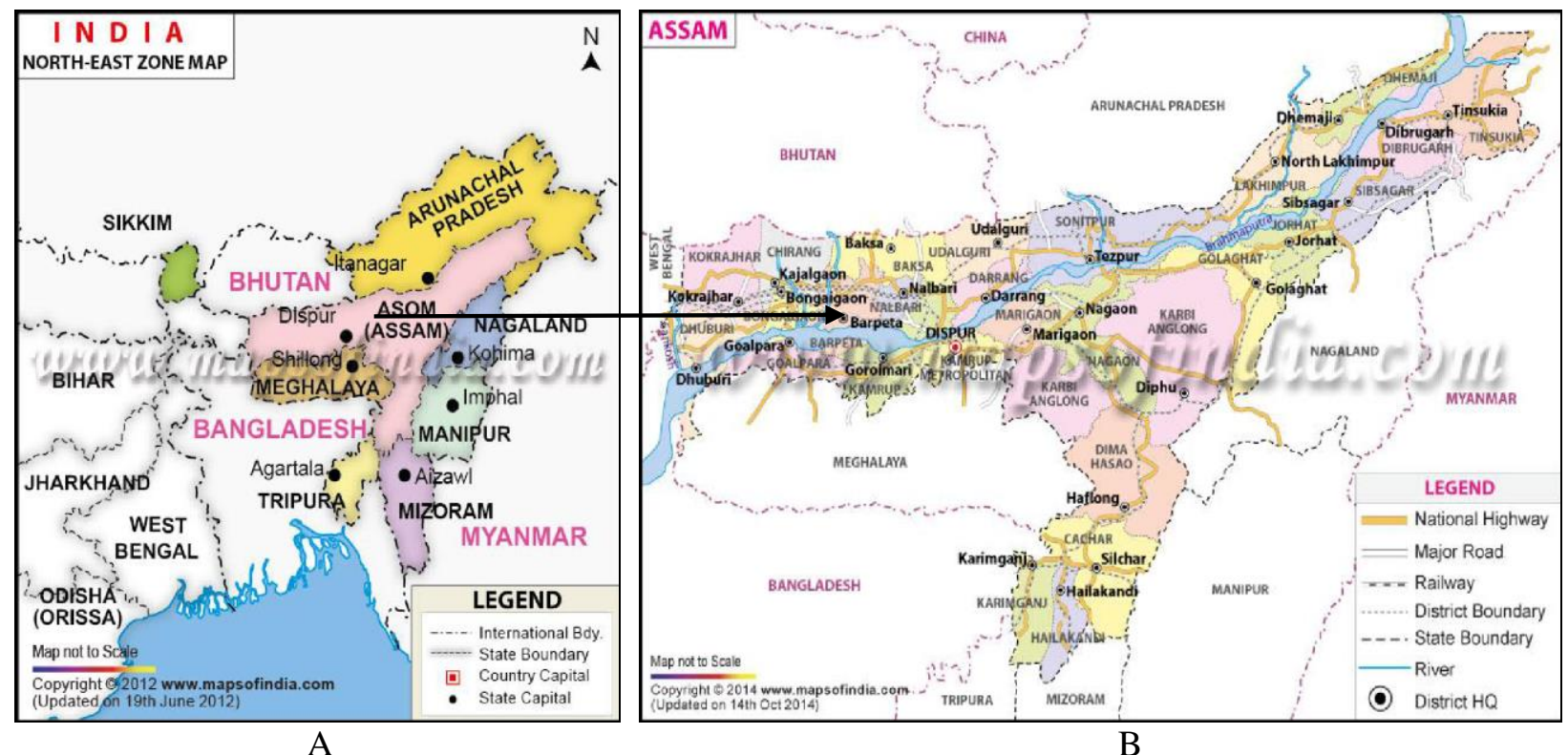

Figure 1. A = Map showing Northeast India (NEI), B = Map of Assam indicating Barpeta district (the sampling area marked by an arrow)

\section{RESULTS}

A total of eighteen interesting rotifer species belonging to five Eurotatoria families and six genera are reported in the systematic list given below:

\section{Phylum Rotifera \\ Class Eurotatoria \\ Subclass Monogononta \\ Order Ploima \\ Family Brachionidae}

1. Brachionus bennini Leissling, 1924 **

2. B. dichotomus reductus Koste \& Shiel, 1980

3. B. durgae Dhanapathi, 1974

4. B. kostei Shiel, 1983

5. Keratella edmondsoni Ahlstrom, 1943

6. K. javana Hauer, 1937

\section{Family Lepadellidae}

7. Lepadella discoidea Segers, 1993

8. L. vandenbrandei Gillard, 1952

\section{Family Lecanidae}

9. Lecane blachei Berzins, 1973

10. L. bulla diabolica (Hauer, 1936)

11. L. lateralis Sharma, 1978

12. L. niwati Segers, Kothetip \& Sanoamuang, 2004

13. L. simonneae Segers, 1993

\section{Family Testudinellidae}

14. Testudinella amphora Hauer, 1938

15. T. brevicaudata Yamamoto, 1951

16. T. dendradena de Beauchamp, 1955*

17. T. greeni Koste, 1981 


\section{Family Trochosphaeridae}

18. Filinia camasecla Myers, 1938

* New record for India; **new record for Assam state

Testudinella dendradena de Beauchamp (Fig. 2) is a new record for India and Brachionus bennini Leissling (Fig. 3) is new record from Assam state. B. dichotomus reductus Koste \& Shiel (Fig. 4) and B. kostei Shiel (Fig. 5) are Australasian elements; Keratella edmondsoni Ahlstrom (Fig. 6), Lecane blachei Berzins (Fig. 7), Lecane bulla diabolica (Hauer) (Fig. 8), L. niwati Segers, Kothetip \& Sanoamuang (Fig. 9) and Filinia camasecla Myers (Fig. 10) are Oriental endemics. Brachionus durgae Dhanapathi (Fig. 11), Keratella javana Hauer (Fig. 12), Lepadella discoidea Segers (Fig. 13), L. vandenbrandei Gillard (Fig. 14), Lecane lateralis Sharma (Fig. 15), L. simonneae Segers (Fig. 16), Testudinella amphora (Fig. 17), T. brevicaudata Yamamoto (Fig. 18), and T. greeni Koste (Fig. 19) are other species with interesting distributions.

\section{DISCUSSION}

Our collections from the sampled beels of lower Assam, NEI revealed eighteen interesting species of Rotifera spread over five eurotatorian families and six genera. Testudinella dendradena is a new record to the Indian Rotifera and Brachionus bennini is a new addition to the rotifer fauna of Assam. The former is treated as a distinct species following Segers (2007) though Jersabek \& Leitner (2013) considered it as T. patina dendradena. We also followed analogies of resurrecttion of Lecane nitida; Mytilina michelangellii and M. brevispina vide Segers \& Savatenalinton (2010), Pourriot (1996) and Luo \& Segers (2014), respectively for the said treatment. $T$. dendradena is diagnosed by its characteristic vitellarium and it co-occurred with $T$. patina in some collections. Further, these two species differed in size and habitat; the former being distinctly larger and preferred the littoral-periphytonic regions. T. dendradena is known from the Afrotropical, Neotropical and Oriental regions (Segers 2007); the present report extended its distribution within the last to the Indian sub-region. B. bennini is reported from the Afrotropical, Australasian, Neotropical, Oriental, and Palaearctic regions (Segers 2007). This brachionid is examined from NEI from Mizoram (Sharma 1987, Sharma \& Sharma 2014d, 2015c) and is also observed from Madhya Pradesh in central India (Sharma \& Naik 1996); the present report extended its distribution within NEI.

The biogeographically interesting elements included: (i) the Australasian Brachionus dichotomus reductus and B. kostei; (ii) five Oriental endemics namely Keratella edmondsoni, Lecane blachei, Lecane bulla diabolica, L. niwati and Filinia camasecla; and (iii) the paleotropical Keratella javana, Lepadella discoidea, $L$. vandenbrandei, Lecane lateralis, L. simonneae, Testudinella brevicaudata and $T$. greeni. Besides, Brachionus durgae, Testudinella amphora and $T$. dendradena merit distribution interest.

Referring to the first category, Segers (2001) remarked on occurrence of reductus vicariant of B. dichotomus outside Australia, hinted at a possible Australian origin of this taxon and hypothesized its recent expansion to Southeast Asia. The disjunct populations of this brachionid known from India only from NEI (Meghalaya, Tripura and Assam) are hypothesized (Sharma \& Sharma 2014a, 2014c, 2014d, 2015b, 2015c) to their possible recent expansions to the Indian subregion. This taxon is reported from the Oriental region from Vietnam (Zhdanova 2011) and from Thailand (Athibai et al. 2013, Sa-Ardrit et al. 2013). Brachionus kostei, described from Australia, is known from Papua Guinea and Thailand while Segers (2007) considered its unpublished report from northeast China as a possible example of introduction. This species is known from India exclusively from Assam state of NEI (Sharma 2004, 2014, Sharma \& Sharma 2008, 2014d, 2015b, Sharma et al. 2015). Nevertheless, these two Australasian elements affirmed affinity of Rotifera assemblage of Assam state as well as of NEI with the faunas of Southeast Asia and Australia, and thus supported remarks of Sharma (2005) and Sharma and Sharma (2005, 2008, 2013, 2014a, 2014c, 2014d). 
Our collections are characterized by five Oriental endemics namely Keratella edmondsoni, Lecane blachei, Lecane bulla diabolica, L. niwati and Filinia camasecla and thus affirmed affinity of Assam Rotifera with the Oriental fauna. The first species was described from Tamil Nadu (Ahlstrom 1943) as K. quadrata var. edmondsoni while Nayar (1965) raised it to the status of a distinct species. This brachionid indicated disjunct occurrence in India with reports from Assam (NEI), Rajasthan, Orissa, and Tamil Nadu. It is reported in the Oriental region from Thailand (SaArdrit et al. 2013) and Cambodia (Meas \& Sanoamuang 2010, Sor et al. 2015). L. blachei, described from Cambodia is also known from Thailand, while its Indian reports are restricted till date to Assam (NEI) and West Bengal (Sharma \& Sharma 2014b). L. bulla diabolica, originally described from Tamil Nadu (Hauer 1936), was known globally by its sole non-illustrated Oriental record from Thailand (Segers \& Savatenalinton 2010) till Sharma \& Sharma (2014b) extended its distribution within India to NEI (Assam, Manipur); the current second Indian report from Assam re-affirmed its distribution in NEI. L. niwati is an interesting lecanid described from Thailand (Segers et al. 2004). Sharma (2014) and Sharma \& Sharma (2014b) recently extended its distribution to NEI based on specimens from the Majuli River Island of upper Assam and Loktak Lake (a Ramsar site), Manipur, respectively while the present study further extended its distribution to lower Brahmaputra river basin. The Oriental $F$. camasecla indicated disjunct occurrence in India with reports from Assam, Manipur and Tripura states of NEI and Kerala (South India).

Amongst the palaeotropical elements, Keratella javana (Assam, Meghalaya, Tripura), Lepadella vandenbrandei (Assam, Mizoram), Testudinella brevicaudata (Assam, Manipur, Tripura) and T. greeni (Assam) merit regional biogeographical interest with their reports so far only from NEI. Lecane simonneae (Assam, Kerala, Manipur, Tripura) exhibited disjunct yet restricted distribution in India while Lepadella discoidea (Assam, Delhi, Kerala, Manipur, Meghalaya) and Lecane lateralis (Assam, Kerala, Meghalaya,
Orissa, Tamil Nadu, Tripura, West Bengal) indicated disjunct but relatively wider occurrence. Besides, the cosmo (sub) tropical Brachionus durgae (Andhra Pradesh, Assam, Goa, Kerala, Maharashtra, Orissa, Tamil Nadu) and Testudinella amphora (Assam) are examples of regional distribution of interest. The latter is known from the Australian, Neotropical and Oriental regions (Segers, 2007); it is examined from the last region from Thailand (Sa-Ardrit et al. 2013) and Vietnam (Trinh Dang et al. 2013), and Sharma et al. (2015) extended its distribution to the Indian sub-region based on collections from the Majuli River Island, upper Assam while Sharma \& Sharma (2015c) recorded it from Mizoram state of NEI. The present report further extends its occurrence to lower Assam.

Keratella javana, Lecane lateralis, L. simonneae, L. unguitata, Lepadella discoidea, L. vandenbrandei, and Testudinella greeni are categorized as Eastern hemisphere elements vide Segers (2001). In addition, three other members of this category: Brachionus diversicornis, B. forficula and $L$. unguitata, though not listed in this report, are observed in our lower Assam samples (BKS, unpublished).The report of the stated taxa imparts yet another interesting character to the rotifer fauna of Assam and NEI.

We categorize all the documented species into three groups: (a) Restricted to NEI: Brachionus dichotomus reductus, B. kostei, Keratella javana, Lepadella vandenbrandei, Lecane blachei, L. niwati, Testudinella amphora, T. brevicaudata, $T$. dendradena and T. greeni; (b) Disjunct and restricted distribution in India: Brachionus bennini, Keratella edmondsoni, Lecane bulla diabolica, $L$. simonneae and Filinia camasecla; (c) Disjunct with relatively wide distribution in India: Brachionus durgae, Lecane lateralis, Lepadella discoidea.

To sum up, the reports of new records, species of global and regional distribution importance and Eastern Hemisphere elements merit biodiversity and biogeographic interest. The Australasian and Oriental species impart special affinity of Assam 
Rotifera with Southeast Asia as well as Australia. The study highlights interesting elements of NEI rotifers as compared with other regions of India. Further, this report is useful addition for metaanalysis of Rotifera diversity of northeast India a global biodiversity region in general and of the floodplain lakes of the Brahmaputra river basin in particular.

Acknowledgements - Thanks are due to the Head of Department of Zoology, North-Eastern Hill University, Shillong for necessary laboratory facilities. The samples examined for the study are collected by one of the authors (SIK). We also thank two anonymous reviewers for useful comments and suggestions.

\section{REFERENCES}

AHLSTROM, E.H. (1943): A revision of the Rotatorian genus Keratella with description of three new species and five new varieties. Bulletin of the American Museum of Natural History, 80: 411-457.

Athibai, S., Segers, H. \& Sanoamuang, L. (2013): Diversity and distribution of Brachionidae (Rotifera) in Thailand, with a key to the species. Journal of Limnology, 72(2): 345-360. doi: 10.4081/jlimnol.2013.s2.e17

HAUER, J. (1936): Neue Rotarien aus Indien I. Zoologischer Anzeiger, 116: 77-80.

JERSABEK, C.D \& LEITNER, M.F. (2013): The Rotifer World Catalog. World Wide Web electronic publication. http://www.rotifera.hausdernatur.at/, accessed $\{20.10 .2015\}$.

Koste, W. (1978): Rotatoria. Die Rädertiere Mitteleuropas, begründet von Max Voigt. Überordnung Monogononta. Gebrüder Borntraeger, Berlin, Stuttgart. I. 673 pp., II. Tafelband. 234 pp.

Luo, Y. \& SEgers, H. (2014): The genus Mytilina in China, with description of a new species (Rotifera: Monogononta: Mytilinidae). Zootaxa, 3846 (4): 561-568. doi: $10.11646 /$ zootaxa.3846.4.4

MEAS, S. \& SANOAMUANG, L. (2010): New records of rotifer fauna in the Cambodian Mekong River Basin. Cambodian Journal of Natural History, 1: 48-62.

NAYAR, C.K.G. (1965): Taxonomic notes on Indian species of Keratella (Rotifera). Hydrobiologia, 26: 457-462. doi: $\underline{10.1007 / B F 00045538}$

POURRIOT, R. (1996): Rotifers from Petit Saut reservoir (French Guyana), with the description of a new taxon. Hydrobiologia, 331: 43-52. doi: $10.1007 / \mathrm{bf} 00025406$
SA-ARdRIT, P., Pholpunthin, P. \& Segers, H. (2013): A checklist of the freshwater rotifer fauna of Thailand (Rotifera, Monogononta, Bdelloidea). Journal of Limnology, 72(2): 361-375. doi: $10.4081 /$ jlimnol.2013.s2.e18

SEGERS, H. (1995): Rotifera 2: Lecanidae. In. H.J. Dumont, T. Nogrady (Eds). Guides to identification of the Microinvertebrates of the Continental waters of the world. SPB Academic Publishing bv. Amsterdam, the Netherlands, 6: 1-226.

SEGERS, H. (2001): Zoogeography of the Southeast Asian Rotifera. Hydrobiologia, 446/447: 233-246. doi: 10.1007/978-94-010-0756-6_32

SEGERS, H. (2007): Annotated checklist of the rotifers (Phylum Rotifera), with notes on nomenclature, taxonomy and distribution. Zootaxa, 1564: 1-104.

Segers, H. \& Savatenalinton, S. (2010): A critical re-revaluation of the Lecanidae (Rotifera: Monogononta) of Thailand, with description of a new species. International Review of Hydrobiology, 95: 343-351. doi: 10.1002/iroh.201011276

Segers, H, Nwadiaro, C.S. \& DUMONT, H.J. (1993): Rotifera of some lakes in the floodplain of the river Niger (Imo State, Nigeria). II. Faunal composition and diversity. Hydrobiologia, 250: 63-71. doi: $10.1007 / \mathrm{BF} 00007495$

Segers, H., Kotethip, W. \& Sanoamuang, L. (2004): Biodiversity of freshwater microfauna in the floodplain of the River Mun, Northeast Thailand: The Rotifera monogononta. Hydrobiologia, 515, 1-9. doi: 10.1023/B:HYDR.0000027299.17844.61

SHARMA, B.K. (1983): The Indian species of the genus Brachionus (Eurotatoria: Monogononta: Brachionidae). Hydrobiologia, 104: 31-39. doi: $10.1007 / \mathrm{BF} 00045949$

SHARMA, B.K. (1987): Indian Brachionidae (Eurotatoria: Monogononta) and their distribution. Hydrobiologia, 144: 269-275. doi: 10.1007/BF00005561

SHARMA, B.K. (1998): Freshwater rotifers (Rotifera: Eurotatoria). State Fauna Series: Fauna of West Bengal, Zoological Survey of India, Calcutta, 3(11): 341-461.

SHARMA, B.K. (2004): Rare and interesting monogonont rotifers (Rotifera: Eurotatoria) from NorthEastern India. Mitteilungen aus dem Museum für Naturkunde Berlin, Zoologische Reihe, 80(1): 3340. doi: $10.1002 / \mathrm{mmnz} .20040800103$

SHARMA, B.K. (2005): Rotifer communities of floodplain lakes of the Brahmaputra basin of lower Assam (N. E. India): biodiversity, distribution and ecology. Hydrobiologia, 533:209-221. doi: 10.1007/s10750-004-2489-3 
SHARMA, B.K. (2014): Rotifers (Rotifera: Eurotatoria) from wetlands of Majuli - the largest river island, the Brahmaputra river basin of upper Assam, northeast India. Check List, 10(2): 292-298 doi: $\underline{10.15560 / 10.2 .292}$

SHARMA, B.K. \& NAIK, L.P. (1996): Results on planktonic rotifers in the Narmada river (Madhya Pradesh, Central India). In. SCHIMER, F. \& BOLAND, K.T. (Eds). Perspectives in Tropical Limnology: SPB Academic Publishing bv. Amsterdam, The Netherlands, p. 189-198.

SHARMA, B.K. \& SHARMA, S. (1997): Lecanid rotifers (Rotifera: Monogononta: Lecanidae) from NorthEastern India. Hydrobiologia, 356: 159-163. doi: 10.1023/A: 1003132516951

SHARMA, B.K. \& SHARMA, S. (1999): Freshwater rotifers (Rotifera, Eurotatoria). Fauna of Meghalaya. State Fauna Series, Zoological Survey of India, Calcutta, 4(9): 11-161.

SHARMA, B.K. \& SHARMA, S. (2000): Freshwater rotifers (Rotifera, Eurotatoria). Fauna of Tripura. State Fauna Series, Zoological Survey of India, Calcutta, 7(4): 163-224.

SHARMA, B.K. \& SHARMA, S. (2005): Biodiversity of freshwater rotifers (Rotifera: Eurotatoria) from North-Eastern India. Mitteilungen aus dem Museum für Naturkunde Berlin, Zoologische Reihe, 81: 8188. doi: $10.1002 / \mathrm{mmnz} .200310002$

SHARMA, B.K. \& SHARMA, S. (2014a): Northeast India - An important region with a rich biodiversity of Rotifera. In. B.K. Sharma, H.J. DumONT, R.L. WALlaCE (Eds). Rotifera XIII: Rotifer Biology- A structural and functional Approach. International Review of Hydrobiology, 99(1-2): 20-37. doi: 10.1002/iroh.201301701

SHARMA, B.K. \& SHARMA, S. (2014b): Indian Lecanidae (Rotifera: Eurotatoria: Monogononta) and its distribution. In. B.K. SHARMA, H.J. DUMONT and R.L. WALlaCE (Eds). Rotifera XIII: Rotifer Biology-A structural and functional approach. International Review of Hydrobiology, 99(1-2): 38-47. doi: 10.1002/iroh.201301702

SHARMA, B.K. \& SHARMA, S. (2014c): Floodplains of the Brahmaputra river basin-globally interesting ecotones with rich Rotifer (Rotifera: Eurotatoria) biodiversity. In. SINHA, R. K. \& AHMED, B.(Eds). Rivers for Life-Proceedings of the International Symposium on River Biodiversity: Ganges-Brahmaputra-Meghna River System, Ecosystems for
Life, A Bangladesh-India Initiative, International Union for Conservation of Nature, p. 258-270.

SHARMA, B.K. \& SHARMA, S. (2014d): The diversity of Indian Brachionidae (Rotifera: Eurotatoria: Monogononta) and their distribution. Opuscula Zoologica Budapest, 45(2): 165-180.

SHARMA, B.K. \& SHARMA, S. (2015a): The diversity and distribution of Lepadellidae (Rotifera: Eurotatoria: Monogononta) of India. International Review of Hydrobiology, 100(1): 34-42. doi: 10.1002/iroh.201401739

SHARMA, B.K. \& SHARMA, S. (2015b): New records of rotifers (Rotifera: Eurotatoria) from Deepor beel- a Ramsar site of India with an update on its Rotifera diversity. Journal of Threatened Taxa, 7(3): 70117016. doi: $\underline{10.11609 / J o T T .04044 .7011-6}$

SHARMA, B.K. \& SHARMA, S. (2015c): Biodiversity of freshwater rotifers (Rotifera: Eurotatoria) of Mizoram, Northeast India: composition, new records and interesting features. International Journal of Aquatic Biology, 3(5): 301-313.

Sharma, B.K., Sharma, S. \& HATIMURia, M.K. (2015): Rotifer assemblages (Rotifera: Eurotatoria) of the floodplain lakes of Majuli River Island, the Brahmaputra river basin, northeast India. International Journal of Aquatic Biology, 3(1): 1-13.

Sharma, S. \& ShARMA, B.K. (2008): Zooplankton diversity in floodplain lakes of Assam. Records of the Zoological Survey of India, Occasional Paper No. 290: 1-307.

SHARMA, S. \& SHARMA, B.K. (2013): Faunal diversity of aquatic invertebrates of Deepor Beel (a Ramsar site), Assam, northeast India. Wetland Ecosystem Series, Zoological Survey of India, Kolkata, 17: 1226.

Sor, R., MEAs, S. \& SEgERS, H. (2015): Diversity of Monogononta rotifer species among standing water bodies in northern Cambodia. Journal of Limnology, 74(1): 192-204. doi: 10.4081/jlimnol.2014.995

Trinh Dang M., Segers, H. \& Sanoamuang, L. (2013): Rotifers from Thuy Tien lake and Nhu Y river in central Vietnam, with a description of Ploesoma asiaticum new species (Rotifera: Monogononta). Journal of Limnology, 72 (2): 276-286. doi: 10.4081/jlimnol. 2013.s2.e19

ZHDANOVA, S.M. (2011): The species composition of rotifers in the water reservoirs of Central Vietnam. Inland Water Biology, 4(4): 425-434. doi: 10.1134/ S1995082911030205 

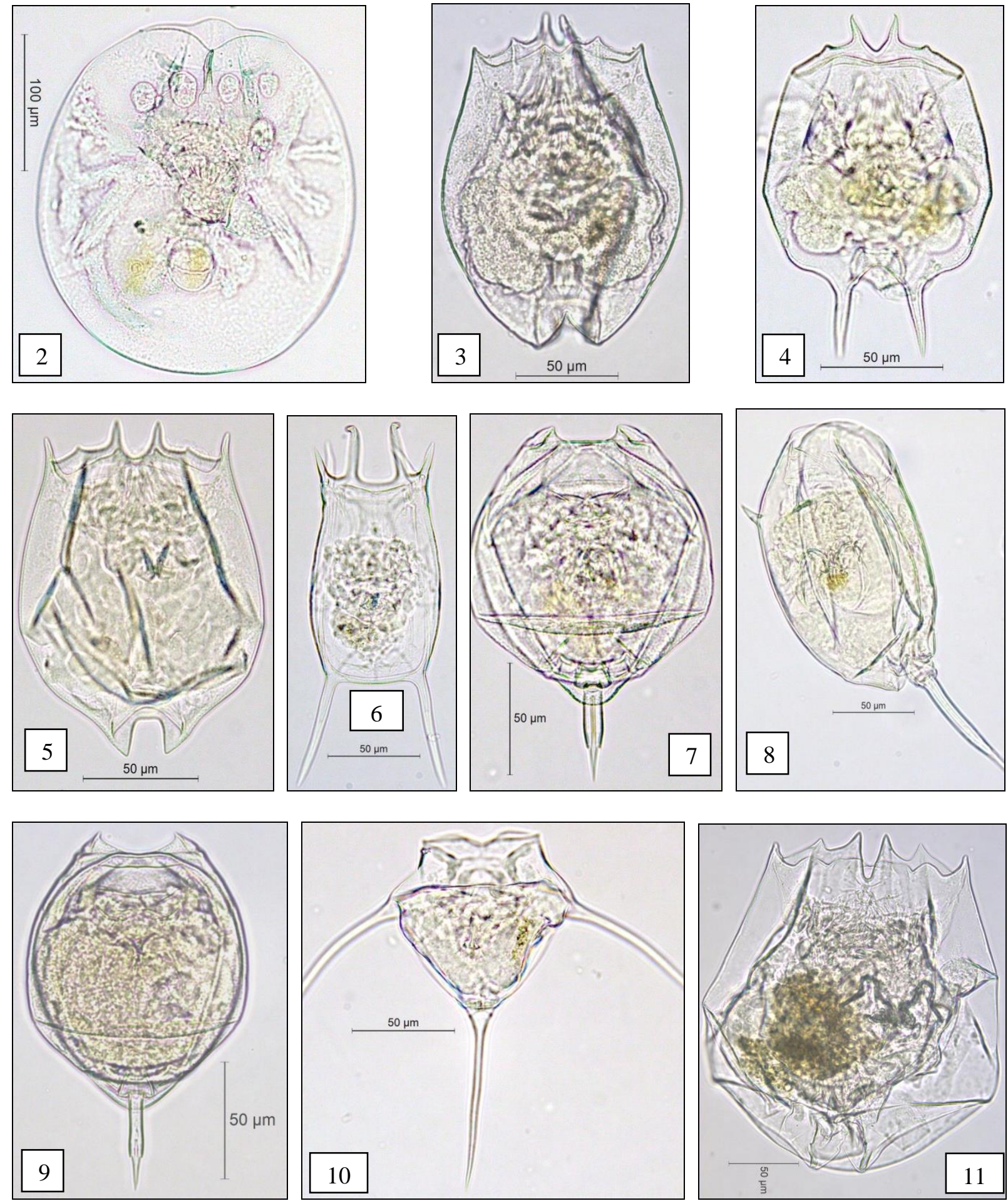

Figures 2-11. 2 = Testudinella dendradena de Beauchamp (ventral view); 3 = Brachionus bennini Leissling (dorsal view); $4=$ Brachionus dichotomus reductus Koste \& Shiel (ventral view); $5=$ Brachionus kostei Shiel (dorsal view); $6=$ Keratella edmondsoni Ahlstrom (dorsal view); 7 = Lecane blachei Berzins (ventral view); $8=$ Lecane bulla diabolica (Hauer) (lateral view); $9=$ Lecane niwati Segers, Kothetip \& Sanoamuang (dorsal view); $10=$ Filinia camasecla Myers (dorsal view);11 = Brachionus durgae Dhanapathi (ventral view). 

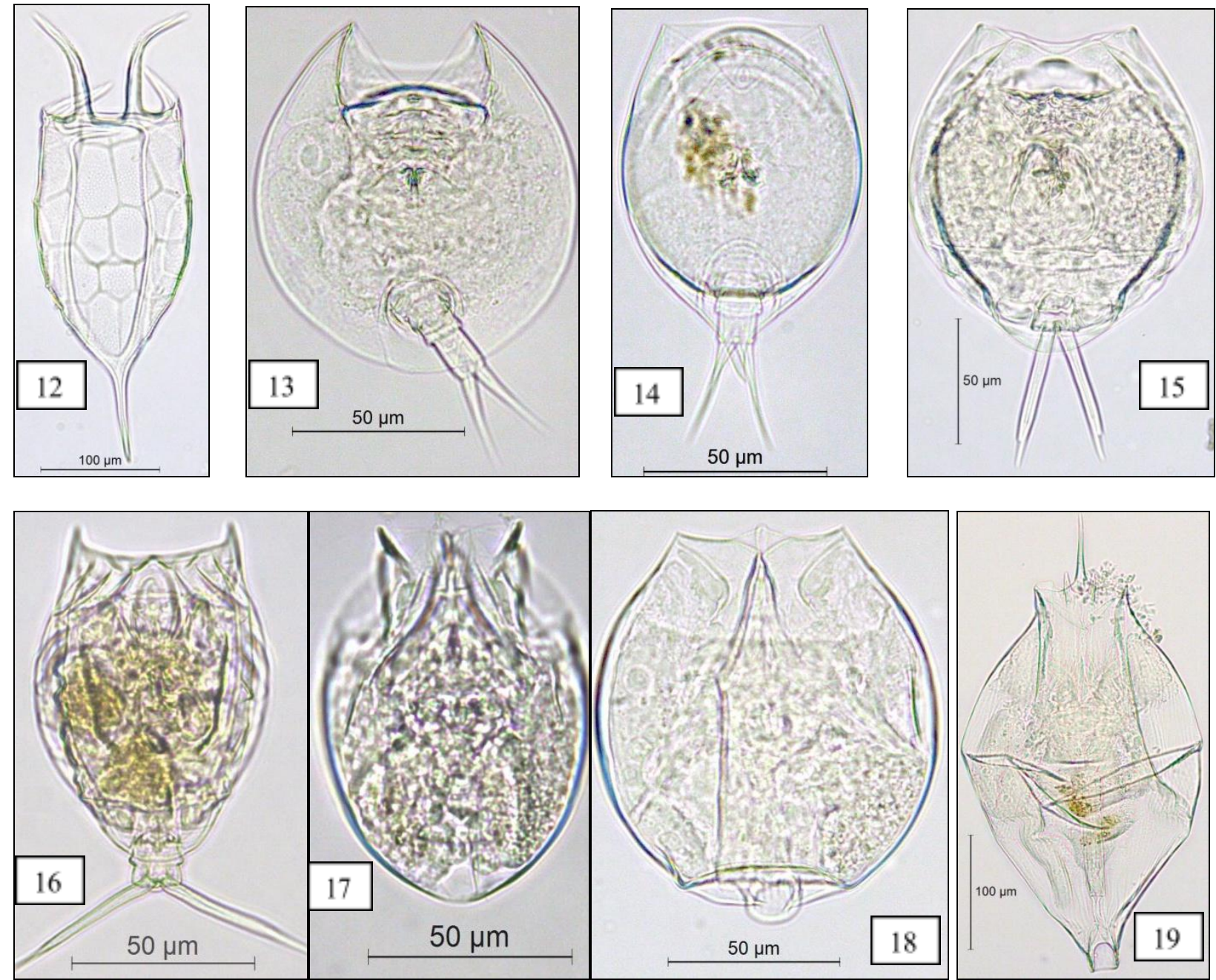

Figures 12-19. 12 = Keratella javana Hauer (ventral view); 13 = Lepadella discoidea Segers (ventral view); 14 = Lepadella vandenbrandei Gillard (ventral view); $15=$ Lecane lateralis Sharma (dorsal view); $16=$ Lecane simonneae Segers (dorsal view); 17 = Testudinella amphora Hauer (dorsal view); 18 = Testudinella brevicaudata Yamamoto (ventral view); 19 = Testudinella greeni Koste (dorsal view). 